\title{
INDIANS AND INVADERS: THE CITIZENSHIP CLAUSE AND ILLEGAL ALIENS
}

\section{Gerard N. Magliocca*}

The Fourteenth Amendment affirms the ancient and fundamental rule of citizenship by birth within the territory, in the allegiance and under the protection of the country, including all children here born of resident aliens, with the exceptions and qualifications (as old as the rule itself) of children of foreign sovereigns or their ministers, or born on foreign public ships, or of enemies within and during a hostile occupation of part of our territory, and with the single additional exception of children of members of the Indian tribes owing direct allegiance to their several tribes.

-United States v. Wong Kim Ark

A constitutional amendment may be required to change the rule whereby birth in this country automatically confers U.S. citizenship, but I doubt it.

-Richard Posner ${ }^{2}$

\section{INTRODUCTION}

Immigration both defines and challenges our national identity, and hence few topics stir more intense feelings than the treatment of illegal aliens (or undocumented workers). ${ }^{3}$ In the current debate on this issue, the courts are taking a back seat to militias, street protests, talk radio, and populist books that are all trying to redefine the legal culture. ${ }^{4}$ Nonetheless, one part of this cacophony that may spill over

* Professor, Indiana University School of Law-Indianapolis. J.D., Yale University I998; B.A., Stanford University 1995. Thanks to my colleagues Dan Cole and Maria Lopez for their thoughtful comments.

1 I69 U.S. 649, 693-94 (I898).

2 Oforji v. Ashcroft, 354 F.3d 609, 621 (7th Cir. 2003) (Posner, J., concurring).

3 Even the terminology used to describe this phenomenon is controversial, as many ohservers think that "illegal alien" is a pejorative term. This Article nonetheless uses that phrase because it is the most common one in public discourse.

4 See, e.g., Peter Yoxall, Comment, The Minuteman Project, Gone in a Minute or Here to Stay? The Origin, History and Future of Citizen Activism on the United States-Mexico Border, $37 \mathrm{U}$. MIAMI INTER-AM. L. REV. 517 (2006) (describing a citizen militia that seeks to draw attention to illegal immigration); Sonya Geis \& Michael Powell, Hundreds of Thousands Rally in 
into litigation is the rule that a child born here to illegal aliens is a citizen." This constitutional custom was not contested for most of the twentieth century but is now under sharp attack for rewarding unlawful action and providing an incentive for foreigners to cross the border. ${ }^{6}$ Indeed, no less an authority than Judge Richard Posner says that the current citizenship policy for these children "makes no sense" and can be repealed by a federal statute.

The origin of a challenge to constitutional orthodoxy is often hard to pinpoint, but in this case the revisionism can be traced to a book written by Peter H. Schuck and Rogers M. Smith in the 1980s. ${ }^{8}$ They argued that the Fourteenth Amendment's mandate-that all persons born here must also be "subject to the jurisdiction" of the United States to be citizens-could be read to exclude the children of illegal aliens. ${ }^{9}$ The historical support for this claim rests in large part

Cities Large and Small, WASH. POST, Apr. 11, 2006, at A8 (noting how hundreds of thousands joined in a national "Day of Action" against what they saw as a punitive immigration bill). For some recent popular books that take a critical look at the issue, see generally Patrick J. Buchanan, State of Emergency: The THiRd WORLd INVASION and CONQUeST OF AMERICA (2006); LOU DOBBS, WAR ON THE Middle Class: HOW THE GOVERNMENT, BIG BUSINESS, AND SPECIAL INTEREST GROUPS ARE WAGING WAR ON THE AMERICAN DREAM AND HOW TO FIGHT BACK (2006).

5 This principle does not rest on any judicial holding. It is based instead on dictum from the Wong Kim Ark case and longstanding practice. See Wong Kim Ark, 169 U.S. at 693-94; see also David A. Martin, Membership and Consent: Absiract or Organic?, 11 YALE J. INT'L L. 278, 280-81 (1985) (reviewing PeTER H. SCHUCK \& ROGERS M. SMITH, CitIZENSHIP WITHOUT CONSENT: ILLEGAL ALIENS IN THE AMERICAN POLITY (1985)) (“Dictum so widely repeated and, apparently, so easily accepted by nearly all Americans may deserve more respect ...."). Thus, it is more accurate to call the rule a form of customary constitutional law.

6 See SCHUCK \& SMITH, supra note 5, at 94-95 ("When . . combined with the powerful lure of the expanded entitlements conferred upon citizen children and their families by the modern welfare state, the total incentive effect of birthright citizenship may well become significant."); Charles Wood, Losing Control of America's Future-The Census, Birthright Citizenship, and Illegal Aliens, 22 HARV.J.L. \& PUB. POL'Y 465, 497 (1999) (contending that the rule "creates a significant additional incentive for illegal immigration").

7 Oforji, 354 F.3d at 621 (Posner, J., concurring). The constitutional custom is codified in 8 U.S.C. $§ 1401$ (2005), and hence Congress would need to take action to alter the status of future children born here to illegal immigrants.

8 See SCHUCK \& SMITH, supra note 5, at 5 (stating that a change in the birthright citizenship for children of illegal aliens "has to our knowledge never been seriously considered"); see also Gerald L. NeUman, StRANGERS TO THE CONSTITUTION: IMMIGRANTS, BORDERS, AND FUNDAMENTAL LAW 166 (1996) (identifying Schuck and Smith's book as the source of the revisionist claims); Joseph $\mathrm{H}$. Carens, Who Belongs? Theoretical and Legal Questions About Birthright Citizenship in the United States, 37 U. TORONTO L.J. 413, 430 (1987) (noting that prior to Schuck and Smith's book, “[f]ew issues of constitutional law ha[d] seemed more clearly settled than birthright citizenship").

9 U.S. CONST. amend. XIV, § I ("All persons born or naturalized in the United States, and subject to the jurisdiction thereof, are citizens of the United States...."); SCHUCK \& 
on the fact that the "subject to the jurisdiction" clause excluded the Native American Tribes from birthright citizenship. ${ }^{10}$ Drawing on this point, Schuck and Smith reasoned that the text requires more than "the individual's subjection to the government's police power and criminal jurisdiction." In their view, there must also be "a reciprocal relationship between them at the time of birth, in which the government consented to the individual's presence and status and offered him complete protection." ${ }^{2}$ Though this analysis is not widely accepted, the book remains an important touchstone in the illegal immigration debate. ${ }^{13}$

This Article untangles the citizenship issue for the children of illegal aliens by showing that Schuck and Smith's analogy to Native Americans is flawed for two reasons. First, the Framers of the Fourteenth Amendment viewed the "subject to the jurisdiction" (or citizenship) clause as a way of enhancing tribal autonomy, not as a tool for limiting citizenship. ${ }^{14}$ As a result, the text does not have an exclu-

SMITH, supra note 5, at 6 (stating that this "expresses a constitutional commitment to citizenship based on mutual consent-the consent of the national community as well as that of the putative individual member"); Wood, supra note 6 , at 509 (" $[\mathrm{T}]$ he rationale that underlies the denial of birthright citizenship to the children of parents who are not fully subject to the formal jurisdiction of the United States applies also to parents who are continuously disobedient, yet cannot in a practical sense be brought before United States courts to answer for it.").

10 See Elk v. Wilkins, 112 U.S. 94, 102 (1884) (confirming this interpretation); S. REP. NO. 41-268, at 10 (1870) ("[T] hose who framed the [F]ourteenth $[\mathrm{A}]$ mendment ... understood that the Indian tribes were not made citizens, but were excluded by the restricting phrase, 'and subject to the jurisdiction' ...."); Neuman, supra note 8, at 167 (stating that Schuck and Smith "focused especially on the denial of citizenship to Native Americans living under tribal authority").

11 SCHUCK \& SMITH, supra note 5, at 86.

$12 I d$.

13 See, e.g., Oforji v. Ashcroft, 354 F.3d 609, 621 (7th Cir. 2003) (Posner, J., concurring) (citing Schuck and Smith's book as authority for his conclusion that Congress probably can repeal by statute birthright citizenship for children born here to illegal aliens); Dan Stein \& John Bauer, Interpreting the 14th Amendment: Automatic Citizenship for Children of Illegal Immigrants?, 7 STAN. L. \& POL'Y REv. 127, 127-28 (1996) (relying on Schuck and Smith to reach the same conclusion). For some of the criticisms, see Christopher L. Eisgruber, Birthright Citizenship and the Constitution, 72 N.Y.U. L. REv. 54, 65-85 (1997) (attacking the normative claims of Schuck and Smith); Neil Gotanda, Race, Citizenship, and the Search for Political Community Among "We the People," 76 OR. L. REV. 233, 248-55 (1997) (pointing out that Schuck and Smith fail to consider the racial implications of their proposal); David S. Schwartz, The Amorality of Consent, 74 CAL. L. REV. 2143, 2152-57 (1986) (reviewing SCHUCK \& SMITH, supra note 5) (rejecting the moral claim of their mutual consent theory).

14 See Gerard N. Magliocca, ANdrew Jackson and the CONSTItUtion: THE Rise ANd Fall OF GENERATIONAL REGIMES 88-93, 118-23 (2007) (exploring how the abuses inflicted on the Tribes influenced the Fourteenth Amendment). 
sionary gloss that should be extended by construction. The revisionists' failure to consider this point reflects a broader problem with our reading of the Fourteenth Amendment. While its drafters viewed Native Americans and African Americans as part of the same battle for freedom, judges and scholars tend to ignore the tribal side of this story. That ongoing omission is harmful because it diminishes the resources available to interpret the landmark provisions of that fundamental constitutional text, including the Citizenship Clause.

More important, comparing illegal immigrants with original native-born inhabitants is conceptually incoherent and leads to an interpretive dead-end. The more appropriate analogy is between illegal aliens and enemy aliens. ${ }^{15}$ At common law, the children born to enemy soldiers in hostile occupation within the dominions of the Crown were not considered subjects. ${ }^{16}$ This exception was widely accepted here when the Fourteenth Amendment was ratified and provides a clear theory for denying citizenship to the offspring of "invaders."17 Accordingly, the question that we should be asking is whether illegal immigration is tantamount to a hostile invasion. This analysis is not only more consistent with the text of the Citizenship Clause, but it also directly engages the views of those who believe that illegal aliens pose a threat to our national security.

Part I reviews the law on birthright citizenship and then lays out the competing view of Schuck and Smith. Part II examines the relationship between the Tribes and the Fourteenth Amendment and shows that the evidence cuts against the claim that the treatment of the Tribes stamps an exclusionary meaning on the "subject to the jurisdiction" clause. Part III argues that a better approach wouId be to take a fresh look at the common law exception for children born to enemy soldiers in hostile occupation and concludes under that analy-

Only one article explores this angle (albeit briefly). See Wood, supra note 6, at 506-08 (drawing on the distinction in Coke's jurisprudence between enemy aliens and aliens in amity).

See, e.g., A. V. DICEY, A DIGEST OF THE LAW OF ENGLAND WITH REFERENCE TO THE CONFLICT OF LAWs 167 (2d ed. 1908) ("Any person who (his father being an alien enemy) is born in a part of the British dominions which at the time of such person's birth is in hostile occupation, is an alien.").

See, e.g., lnglis v. Trs. of Sailor's Snug Harbour, 28 U.S. (3 Pet.) 99, 156 (1830) (Story, J., dissenting) (" $[T]$ he children of enemies, born in a place within the dominions of another sovereign, then occupied by them by conquest, are still aliens ...."); JAMES KENT, 2 COMMENTARIES ON AMERICAN LAW 90 (spec. ed., 1986) (1827) (stating that children of aliens born here in hostile occupation were not citizens); see also Calvin's Case, (1608) 77 Eng. Rep. 377, 398-99 (K.B.) (establishing this rule). 
sis that illegal immigration is not the functional equivalent of a foreign invasion for citizenship purposes.

\section{The Challenge to AN Age-Old Rule}

This Part traces the doctrine on birthright citizenship from the common law through the ratification of the Fourteenth Amendment. Under the conventional view of these authorities, a child born here to aliens is a citizen so long as the United States has legal and actual authority over the parents-including illegal aliens. ${ }^{18}$ Schuck and Smith read these same sources as holding that reciprocal consent to citizenship is required by the Fourteenth Amendment, which would exclude illegal aliens. ${ }^{19}$ This split between the territorial and mutual allegiance interpretations of the "subject to the jurisdiction" clause defines the current impasse.

\section{A. Birthright Citizenship and the Common Law}

One fundamental premise of Anglo-American jurisprudence is that any child born within the dominion and under the authority of

See, e.g., Societal and Legal Issues Surrounding Children Born in the United States to Illegal Alien Parents: Joint Hearing on H.R. 705, H.R. 1363, H.J. Res. 56, H.J. Res. 64, H.J. Res. 87, H.J. Res. 88, and H.J. Res. 93 Before the Subcomm. on Immigration E' Land Claims and the Subcomm. on the Constitution of the H. Comm. on the Judiciary, 104th Cong. 103-04 (1995) (statement of Gerald L. Neuman, Professor, Columbia University Law School) ("[S]ubject to the jurisdiction," in the Citizenship Clause "means actual subjection to the lawmaking power of the United States... The common law exceptions included children of foreign diplomats, who were legally immune from domestic law, and children born to women accompanying invading armies, who were practically immune from domestic law."); Wood, supra note 6, at 518 (stating that the Citizenship Clause's "subject to" phrase "requires not only formal jurisdiction, but also more than some minimum degree of actual power on the part of the United States to bring the parents to justice for disobeying federal law"); see also In re Look Tin Sing, 21 F. 905, 906 (C.C.D. Cal. 1884) (stating that jurisdiction under the Citizenship Clause must be "actual and exclusive").

19 See Schuck \& SMITH, supra note 5, at 116 ("[The Citizenship Clause] should be read to embody the public law's conception of consensual membership, and therefore to refer only to ... citizens and legal resident aliens."); see also Michael Gunlicks, Note, Citizenship as a Weapon in Controlling the Flow of Undocumented Aliens: Evaluation of Proposed Denials of Citizenship to Children of Undocumented Aliens Borm in the United States, 63 GEO. WASH. L. REV. 551,567 (1995) ("[Schuck and Smith] argue that a consensual allegiance to the United States and consensual protection by the United States, not territorial happenstance, should be the bases of citizenship for everyone."). Critics respond that the Fourteenth Amendment itself gave consent to birth citizenship and the contemporary consent of Congress is not required. See NEUMAN, supra note 8, at 169 (" $[\mathrm{A}]$ consensual approach to citizenship need not imply anything about the powers of Congress."). Thus, a more accurate description of the revisionist view is that Congress retains the discretion to exclude illegal aliens from citizenship. 
the sovereign is a citizen. ${ }^{20}$ In the seventeenth century, Lord Coke held, "Every man is either alienigena, an alien born, or subditus, a subject born. Every alien is either a friend that is in league, \&c. or an enemy that is in open war...."21 With respect to enemy aliens, Coke said that if they "surprise any castle or fort, and possess the same by hostility, and have issue there, that issue is no subject to the King, though he be born within his dominions, for that he was not born under the King's ligeance or obedience." ${ }^{22}$ By contrast, allied or friendly aliens "owed to the King local obedience, that is, so long as he was within the King's protection; which local obedience, being but momentary and uncertain, is yet strong enough to make a natural subject; for if he hath issue here, that issue is a natural born subject...."23 The only exception to this rule was an ambassador, who was an official representative of a foreign prince and thus owed him allegiance even when abroad. ${ }^{24}$

Although Coke's reasoning relied on a feudal premise about the indissoluble tie between lord and subject, his formulation was adopted by the United States. ${ }^{25}$ The Supreme Court observed that

20 See United States v. Wong Kim Ark, 169 U.S. 649, 655 (1898) ("The fundamental principle of the common law with regard to English nationality was birth within the allegiance ... ."); see also Inglis, 28 U.S. (3 Pet.) at 164 (Story, J., dissenting) ("Nothing is better settled at the common law than the doctrine that the children even of aliens born in a country, while the parents are resident there under the protection of the government, and owing a temporary allegiance thereto, are subjects by birth.").

21 Calvin's Case, 77 Eng. Rep. at 397; see Polly J. Price, Natural Law and Birthright Citizenship in Calvin's Case (1608), 9 YALE J.L. \& Human. 73, 74 (1997) ("Calvin's Case became the basis of the American common-law rule of birthright citizenship, a rule that was later embodied in the Fourteenth Amendment ...." (footnote omitted)).

22 Calvin's Case, 77 Eng. Rep. at 399.

23 Id. at 384; cf. Schooner Exch. v. McFaddon, 11 U.S. (7 Cranch) 116, 144 (1812) ("When private individuals of one nation spread themselves through another as business or caprice may direct, ... it would be obviously inconvenient and dangerous ... if such individuals or merchants did not owe temporary and local allegiance, and were not amenable to the jurisdiction of the country.").

24 See Calvin's Case, 77 Eng. Rep. at 399 ("[1]f any of the King's ambassadors in foreign nations, have children there of their wives, being English women, by the common laws of England they are natural-born subjects, and yet they are horn out of the King's dominions."); see also Inglis, 28 U.S. (3 Pet.) at 155 ("[T] he children of an ambassador are held to be subjects of the prince whom he represents, although boru under the actual protection and in the dominions of a foreign prince.").

25 See Wong Kim Ark, 169 U.S. at 707 (Fuller, C.J., dissenting) ("The rule was the outcome of the connection in feudalism hetween the individual and the soil on which he lived, and the allegiance due was that of liegemen to their liege lord."); Bernadette Meyler, The Gestation of Birthright Citizenship, 1868-1898 States' Rights, The Law of Nations, and Mutual Consent, 15 GEO. 1MMIGR. L.]. 519, 528 (2001) ("Courts in the early United States continued to follow the jus soli principles that Coke had articulated in Calvin's Case."). A related exception was created for anyone born on a foreign public ship in our waters. See Schooner 
the birth citizenship rule for aliens "does not appear to have been contested or doubted until more than fifty years after the adoption of the Constitution." ${ }^{26}$ And when a challenge was made in Lynch $v$. Clarke, ${ }^{27}$ a New York court reaffirmed the common law approach and rejected a reciprocal consent theory of citizenship. ${ }^{28}$ lndeed, Lynch held that "every person born within the dominions and allegiance of the United States, whatever were the situation of his parents, is a natural born citizen." ${ }^{29}$

This unequivocal statement of liberty, like so many others in our tradition, was not applied to slaves and most Native Americans. In the slave states, positive law simply ousted the common law and denied African Americans citizenship. ${ }^{30}$ The Tribes presented a more complex problem that had no common law counterpart. While they lived within the United States, most Native Americans retained their tribal identity and considered themselves as coequal sovereigns. ${ }^{31}$ This status was confirmed by the regular practice of signing treaties

Exch., 11 U.S. (7 Cranch) at 144-45 (holding that the United States lacks jurisdiction over these vessels); In re Look Tin Sing, 21 F. 905,906 (C.C.D. Cal. 1884) ("Persons born on a public vessel of a foreign country, while within the waters of the United States ... are also excepted. They are considered as born in the country to which the vessel belongs.").

Wong Kim Ark, 169 U.S. at 664; see SCHUCK \& SMITH, supra note 5, at 57-58 (" [A]lthough children born in America of alien parents were generally assumed to be citizens who possessed all the rights and obligations of that status, no court seems to have decided a case directly on the question until Lynch $v$. Clarke, a New York case decided in 1844.").

271 Sand. Ch. 583 (N.Y. Ch. 1844).

28 Id. at 673-79; see also Carens, supra note 8, at 431 ("Lynch v. Clarke ... explicitly rejected Vattel's public law conception of consensual membership."). Nevertheless, Schuck and Smith find comfort in this decision because it proves that "the issue was still unsettled even in 1844." See SCHUCK \& SMITH, supra note 5, at 61 . This assertion is false. Although there were some treatise writers who argued against birthright citizenship, no court ever accepted this view.

291 Sand. Ch. at 663; see In re Look Tin Sing, 21 F. at 909 (stating that the issue "was elaborately considered" in Lynch and that the conclusion "was the general understanding of the legal profession, and the universal impression of the public mind"). This dictum could be cited as support for birth citizenship of illegal aliens, but the holding of $L y n c h$ addressed the status of a child born to a foreign visitor. See Lynch, 1 Sand. Ch. at 638.

30 By this time, English law held that slavery was contrary to the common law presumption of freedom and could only be supported by positive law. See, e.g., Dred Scott v. Sandford, 60 U.S. (19 How.) 393, 412-13 (1857) (stating that in slave states, African-Americans "have never been regarded as a part of the people or citizens of the State, nor supposed to possess any political rights which the dominant race might not withhold or grant at their pleasure"); Somerset v. Stewart, (1772) 98 Eng. Rep. 499, 510 (K.B.) (Mansfield, L.J.) (stating that slavery is "so odious, that nothing can be suffered to support it, but positive lawn).

31 For an illuminating discussion of these issues, see Chancellor Kent's opinion in Goodell v. Jackson, 20 Johns. 693 (N.Y. 1823), which held that tribal members owe allegiance to a tribe and not to the United States. 
with the Tribes, just as the President did with foreign nations. ${ }^{32}$ Thus, the consensus view was that the United States lacked jurisdiction over these "domestic dependent nations" and that the Tribes were on the same legal plane as foreign ambassadors with respect to citizenship. ${ }^{39}$

Among its many faults, Dred Scott $v$. Sandford broke with the common law tradition by holding that birthright citizenship did not apply to free African Americans. ${ }^{34}$ While the lead dissent observed that "it is a principle of public law, recognised by the Constitution itself, that birth on the soil of a country both creates the duties and confers the rights of citizenship," Chief Justice Taney responded "that neither the class of persons who had been imported as slaves, nor their descendants, whether they had become free or not, were ... intended to be included" among our citizenry. ${ }^{36}$ As Schuck and Smith observed, "By making Dred Scott's citizenship turn upon the putative will and intention of the Framers to exclude all blacks from the American political community, Taney seemed to embrace the consensual conception of citizenship...."37 Of course, this result was overruled by the Fourteenth Amendment. ${ }^{38}$

See Worcester v. Georgia, 31 U.S. (6 Pet.) 515, 559-61 (1832); see also 6 REG. DEB. 349 (1830) (statement of Sen. Sprague) (stressing this point in opposing President Jackson's plan to aid the removal of the Cherokees from Georgia).

33 See Cherokee Nation v. Georgia, 30 U.S. (5 Pet.) 1, 17 (1831) (establishing this definition of the Tribes); see also Elk v. Wilkins, 112 U.S. 94, 100 (1884) (explaining that the Tribes were not subject to birthright citizenship prior to the Civil War). The constitutional generation led by Andrew Jackson reversed this view of tribal sovereignty, arguing that Congress or the several states possessed full authority to govern the Tribes. See United States v. Rogers, 45 U.S. (4 How.) 567, 572 (1846) (“[T]ribes residing within the territorial limits of the United States are subject to their authority, and where the country occupied by them is not within the limits of one of the States, Congress may by law punish any offence committed there ...."); MAGLIOCCA, supra note 14, at 95 ("[A]s Jackson had always maintained, Congress and the states could govern Native Americans without restriction."). Even during this period, though, the Tribes retained their sovereignty in the sense that the United States continued to make treaties with them, and thus birthright citizenship did not apply.

34 See Dred Scott, 60 U.S. (19 How.) at 407 (stating that neither the Declaration of Independence nor historical legislation allows for such citizenship).

35 Id. at 578 (Curtis, J., dissenting); see U.S. CoNST. art. 11, $\$$ I, cl. 5 (stating that “[n]o Person except a natural born Citizen" is eligible for the Presidency). Dred Scott, 60 U.S. (19 How.) at 407.

37 SCHUCK \& SMITH, supra note 5 , at 72.

38 In this sense, the revisionist argument that the Fourteenth Amendment repudiated the holding of Dred Scott but embraced its reasoning is implausible. See Carens, supra note 8, at 437 ("Schuck and Smith clearly want to repudiate, on moral grounds, the treatment of blacks . . . endorsed by Dred Scott . . . but at the same time they want to draw on the arguments used to justify those decisions.... This is a difficult and a dangerous line and one that is ultimately impossible to sustain."). 


\section{B. The Fourteenth Amendment and Wong Kim Ark}

When the Thirty-Ninth Congress got down to work, the conventional view is that they sought to affirm the common law approach to birthright citizenship and extend the rule to the newly freed slaves. ${ }^{39}$ The Civil Rights Act of 1866, which was the direct antecedent of the Fourteenth Amendment, held that "all persons born in the United States and not subject to any foreign power, excluding lndians not taxed, are hereby declared to be citizens of the United States. ${ }^{40}$ During the debate on the Act, common law precedents such as Lynch were cited to illustrate the meaning of birthright citizenship. ${ }^{41}$ While the language on "Indians not taxed" was taken from the Constitution to indicate that the exclusion of the Tribes would continue, ${ }^{42}$ the phrase "subject to any foreign power" referred to the traditional exceptions for children of ambassadors and enemy aliens in hostile occupation. ${ }^{43}$

When Republicans decided to secure and broaden the Civil Rights Act through the Fourteenth Amendment, the relevant text was changed to say that all Americans "subject to the jurisdiction" of the United States were birthright citizens. Once again, the common law

See United States v. Wong Kim Ark, 169 U.S. 649, 675 (1898) ("In the fore front, both of the Fourteenth Amendment of the Constitution, and of the Civil Rights Act of 1866, the fundamental principle of citizenship by birth within the dominion was reaffirmed in the most exphicit and comprehensive terms."); id. at 676 (stating that the Citizenship Clause "is declaratory in form, and enabling and extending in effect").

40 Act of Apr. 9, I866, ch. 31, I4 Stat. 27.

41 See CONG. GlobE, 39th Cong., 1st Sess. I832 (1866) (statement of Rep. Lawrence) ("In the great case of Lynch vs. Clarke, it was conclusively shown ... that all 'children born here are citizens without any regard to the political condition or allegiance of their parents.' "); cf. In re Look Tin Sing, 2I F. 905, 909 (C.C.D. Cal. 1884) (using Lynch to interpret the text).

42 See U.S. CONST. art. I., \$ 2, cl. 3 ("excluding Indians not taxed" for the apportionment of representatives and direct taxes). Congress granted birthright citizenship to all Native Americans by statute in 1924. See Act of June 2, 1924, ch. 233, 43 Stat. 253 (current version at 8 U.S.C. $\S \mathrm{I} 401$ (b) (2000)).

43 One scholar says that this language meant that "[a]ny child born on U.S. soil to parents who were temporary visitors to this country and who, as a result of the foreign citizenship of the child's parents, remained a citizen or subject of the parents' home country, was not entitled to claim ... birthright citizenship." John C. Eastman, Politics and the Court: Did the Supreme Court Really Move Left Because of Embarrassment over Bush v. Gore?, 94 GEO. L.J. 1475,1486 (2006). This expansive reading is not supported by any evidence, and is contradicted by the citation to Lynch, which held that a child born to a foreign visitor is a citizen. See Lynch v. Clarke, 1 Sand. Ch. 583, 683 (N.Y. Ch. 1844); CONG. GLOBE, 39th Cong., 1st Sess. 498 (1866) (statement of Sen. Trumbull) ("I understand that under the naturalization laws the children who are born here of parents who have not been naturalized are citizens. That is the law, as I understand it, at the present time. ${ }^{n}$ ). 
was invoked to define this language, but the debate centered on whether this substitute applied to the Tribes. ${ }^{44}$ Some contended that federal statutes already regulated aspects of tribal life and subjected Native Americans to national jurisdiction. ${ }^{45}$ Nonetheless, the phrase was retained because the floor managers could not agree on a better alternative. ${ }^{46}$ Furthermore, they countered that the Tribes were not "subject to the jurisdiction" of the United States because they had their own recognized governments. ${ }^{47}$

In United States $v$. Wong Kim Ark, ${ }^{48}$ the Supreme Court held that the Fourteenth Amendment adopted the common law view of birthright citizenship. ${ }^{49}$ Ruling that children born in the United States to Chi-

44 See, e.g., CONG. GLOBE, 39th Cong., 1st Sess. 2890 (1866) (statement of Sen. Howard) ("This amendment which I have offered is simply declaratory of what I regard as the law of the land already...."); id. at 2769 (statement of Sen. Wade) (invoking the foreign ambassador exception). Nothing in the dehates sheds any light on the issue of illegal aliens. The only related reference came from a foe of the Amendment who complained that it would grant birth citizenship to gypsies. Id. at 2891 (statement of Sen. Cowan). He argued that the State had a right to reject gypsies because they "invade her borders; who owe to her no allegiance; who pretend to owe none; who recognize no authority in her government; who have a distinct, independent government of their own-an imperium in imperio." Id. Some of these faults can he attributed to illegal immigrants, but they do not have their own government.

45 Id. at 2892 (statement of Sen. Doolittle); id. at 2893-94 (statement of Sen. Johnson); id. at 2894-95 (statement of Sen. Hendricks).

46 See id. at 2894-97. In particular, the formulation of "Indians not taxed" was rejected because it implied that states could control the definition of citizenship by changing tax policy and might introduce wealth discrimination into the Constitution. See id. at 2894 (statement of Sen. Trumbull) (“[1]t would be very objectionable to insert those words here, because it would make of a wealthy Indian a citizen and would not make a citizen of one not possessed of wealth under the same circumstances."); id. at 2895 (providing a colloquy on whether changes in state taxes would affect Native American citizenship).

47 See id. at 2895 (statement of Sen. Howard) (explaining that "the jurisdiction of the [tribal] nation intervenes and ousts what would otherwise be perhaps a right of jurisdiction of the United States"); id. at 2893 (statement of Sen. Trumbull) ("We make treaties with them, and therefore they are not subject to our jurisdiction."); see also In re Look Tin Sing, 21 F. 905, 909 n.2 (C.C.D. Cal. 1884) ("These tribes are independent political communities, retaining, in many respects, the right of self-government ...; and a member thereof, though born in the country, is not, by his birth, a citizen of the United States, under the [F]ourteenth $[\mathrm{A}]$ mendment. He is not born under their actual and exclusive jurisdiction, which the $[\mathrm{A}]$ mendment contemplates.").

48169 U.S. $649,681(1898)$.

49 See id. at 563 ("The question ... is whether a child born in the United States, of parents of Chinese descent, who at the time of his birth are subjects of the Emperor of China,$\ldots$ and are not employed in any diplomatic or official capacity ..., hecomes at the time of his birth a citizen of the United States...."). In its first reading of the Fourteenth Amendment, the Court stated, "The phrase 'subject to its jurisdiction' was intended to exclude from its operation children of ministers, consuls, and citizens or subjects of foreign States, born within the United States." Slaughter-House Cases, 83 U.S. (16 Wall.) 36, 73 (1873). This dicta from Slaughter-House was rejected as erroneous in 
nese immigrants were citizens, the Justices "detailed at some length the history of the Citizenship Clause, and the predominantly geographic sense in which the term 'jurisdiction' was used." ${ }^{50}$ They concluded that the purpose of the "subject to the jurisdiction" language:

[W]ould appear to have been to exclude, by the fewest and fittest words, (besides children of members of the Indian tribes, standing in a peculiar relation to the National Government, unknown to the common law,) the two classes of cases-children born of alien enemies in hostile occupation, and children of diplomatic representatives of a foreign State-both of which, as has already been shown, ... had been recognized exceptions to the fundamental rule of citizenship by birth within the country."

The emphasis on territoriality was an integral part of the common law approach dating back to Coke, which held that citizenship was directly tied to the government's legal and practical authority. ${ }^{52}$

\section{A Mutual Consent Approach to Citizenship}

The Court has not revisited Wong Kim Ark, but Schuck and Smith offer a reading of the Citizenship Clause that connects the exclusions to birthright citizenship with a principle of reciprocal consent or allegiance. After conceding that the common law held that citizenship applied to aliens "under circumstances in which the sovereign possessed the power to provide protection to the subject and was actually exercising it to at least some minimal degree," they argue that deter-

Wong Kim Ark. See Wong Kim Ark, 169 U.S. at 678 ("It was unsupported by any argument, or by any reference to authorities; and . . . was not formulated with the same care and exactness, as if the case before the court had called for an exact definition of the phrase ...."). I was sympathetic to recent rehabilitation efforts on behalf of SlaughterHouse, see Kevin Christopher Newsom, Setting Incorporation Straight: A Reinterpretation of the Slaughter-House Cases, I09 YALE L.J. 643, 648-49 (2000), but this error on the Citizenship Clause leads me back to the conclusion that Justice Miller's opinion for the Court really was a sloppy effort.

50 Plyler v. Doe, 457 U.S. 202, 211 n.10 (1982). At the time, this question was controversial because naturalization laws barred parents of Asian descent from becoming citizens; thus, some commentators argued that their children were excluded from birthright citizenship. See also Meyler, supra note 25, at 532-37 (describing the lively discussion of this issue in the law reviews).

$51 \quad$ Wong Kim Ark, 169 U.S. at 682.

52 See supra notes 21-24 and accompanying test. Compare CONG. GLOBE, 39th Cong., 1st Sess. 2897 (1866) (statement of Sen. Williams) (“All persons living within a judicial district may be said, in one sense, to be subject to the jurisdiction of the court in that district, but they are not in every sense subject to the jurisdiction of the court until they are brought, by proper process, within the reach of the power of the court."), with Eastman, supra note 43, at I488 (concluding that Wong Kim Ark did not "appreciate[] the distincuion between partial, territorial jurisdiction, which subjects all who are present within the territory of a sovereign to the jurisdiction of its laws, and complete, political jurisdiction, which requires allegiance to the sovereign as well."). 
mining status by birth was in tension with the democratic ideal that citizenship was a matter of personal choice. ${ }^{53}$ For instance, the common law held that citizenship could not be renounced, as the bond between subject and King was perpetual. ${ }^{54}$ The Founders rejected this principle in the Declaration of Independence, and the same Congress that ratified the Fourteenth Amendment also passed the Expatriation Act, which stated that it was "a natural and inherent right of all people" to renounce their citizenship. ${ }^{55}$ Thus, mutual consent and birthright citizenship were each living traditions when the "subject to the jurisdiction" provision was written.

Schuck and Smith further contend that this clause modified birthright citizenship with a consent requirement, and their leading evidence comes from the debate about the Tribes. ${ }^{56}$ When Senator Trumbull was asked why jurisdiction was lacking over the Tribes, he said that the term meant "[n]ot owing allegiance to anybody else." In a similar vein, Senator Howard stated that the Tribes were excluded because "full and complete" jurisdiction was required, which

53 SCHUCK \& SMITH, supra note 5, at 14; see id. at 23-36 (summarizing the arguments made by Locke and other writers on behalf of a consent theory). In most respects, Schuck and Smith track the views expressed by the dissenters in Wong Kim Ark. See Carens, supra note 8, at 434 ("The similarities between [the dissenters'] line of argument and the one advanced by Schuck and Smith could hardly be more striking."). This is awkward because they agree with the holding of the case, just as they disagree with the holding of Dred Scott while backing its consent-based approach to citizenship. See supra note 38. One scholar explains that " $[t]$ he unintended but inevitable consequence of Schuck and Smith's reasoning would be the symbolic rehabilitation of Dred Scott . . . and the symbolic repudiation of Wong Kim Ark." Carens, supra note 8, at 437.

54 See Calvin's Case, (1608) 77 Eng. Rep. 377, 407 (K.B.) (stating that allegiance was irrevocable). Accordingly, the Royal Navy held that it had the right to impress Americans into its service long after the Revolution because they were British subjects for life. See also SCHUCK \& SMITH, supra note 5, at 54.

55 SCHUCK \& SMITH, supra note 5, at 86-87; see also Wong Kim Ark, 169 U.S. at 711 (Fuller, C.J., dissenting) (" $[\mathrm{F}]$ rom the Declaration of Independence to this day, the United States have rejected the doctrine of indissoluble allegiance and maintained the general right of expatriation, to be exercised in subordination to the public interests and subject to regulation.").

56 See SCHUCK \& SMITH, supra note 5, at 85-86 (stating that the jurisdiction rule "added to the ineradicably ascriptive birthright citizenship rule a transforming consensual conception of the necessary connection between an individual and his government-a conception that was ... more profoundly political tban one emphasizing the individual's mere presence on the soil at birth"); id. at 84-85 ("[T] he jurisdiction requirement was elaborated most fully and carefully in connection with the congressional debates (and later adjudication) over the question of Indian birthright citizenship ....").

57 CONG. GLOBE, 39th Cong., Ist Sess. 2893 (I866) (statement of Sen. Trumbull). If this quote were taken seriously, then dual citizenship would be prohibited. See Wong Kim Ark, 169 U.S. at 720 (Fuller, C.J., dissenting) ("[D]ouble allegiance in the sense of double nationality has no place in our law...."). 
would be the same "in extent and quality as applies to every citizen of the United States now. ${ }^{\text {"58 }}$ Both statements support what Schuck and Smith describe as a "more demanding formulation" of jurisdiction that required national authority and consent to citizenship. ${ }^{59}$ They also cite the Court's opinion in Elk $v$. Wilkins, ${ }^{60}$ which held the Tribes were not entitled to birthright citizenship because the clause meant "not merely subject in some respect or degree to the jurisdiction of the United States, but completely subject to their political jurisdiction, and owing them direct and immediate allegiance." ${ }^{\text {"1 }}$ In the Court's words, this expressed a "principle that no one can become a citizen of a nation without its consent."

The revisionist argument does provide a reasonable basis for the continuation of the common law exceptions into the modern era. Instead of viewing the ambassador and tribal categories as situations where the United States lacks the legal authority to grant birthright citizenship, Schuck and Smith observe that in each case there was no consent to citizenship by both sovereigns. ${ }^{63}$ Enemy aliens in hostile occupation did not fall under the actual authority of the government at common law, but one could also say that birthright citizenship was inappropriate because a sovereign did not consent to the presence of foreign troops on its soil. Reciprocal allegiance therefore makes as much sense of these precedents as a territorial view of jurisdiction.

Theories of territory and mutual allegiance part company on the issue of illegal aliens. Stated simply, these immigrants would be excluded from birth citizenship under a consent approach because the

58 ConG. Globe, 39th Cong., 1st Sess. 2895 (1866) (statement of Sen. Howard).

59 SCHUCK \& SMITH, supra note 5, at 82-83.

60112 U.S. 94 (1884).

61 Id. at 102 (1884). In Wong Kim Ark, the Court limited this case to its facts. See Wong Kim Ark, 169 U.S. at 682 ("The decision in Elk v. Wilkins concerned only members of the lndian tribes within the United States, and had no tendency to deny citizenship to children born in the United States of foreign parents of Caucasian, African or Mongolian descent, not in the diplomatic service of a foreign country.").

$62 E l k, 112$ U.S. at 103 . The issue in $E l k$ was whether a Native American automatically became a citizen when he left his tribe and subjected himself to the jurisdiction of the United States. Though there was significant evidence that the Framers of the Fourteenth Amendment wouId have said yes, the Court held that these individuals would have to apply for naturalization just like any other alien. See also Gerard N. Magliocca, The Cherokee Removal and the Fourteenth Amendment, 53 DUKE L.J. 875, 945, 950 (2003) (looking at the decision and the legislative history).

63 See SCHUCK \& SMITH, supra note 5, at 85 (stating that "this privileged status of diplomats was one to which both governments consented"); id. at 83 (stating that the Tribes "had never chosen or been chosen to be United States citizens"). 
United States does not consent to their presence. ${ }^{64}$ But under a formulation based on the authority of the federal government, illegal aliens are included so long as they are not beyond the reach of the authorities, as is the case when territory is occupied by a foreign power. To resolve this dispute, we must choose between these competing readings of the "subject to the jurisdiction" clause.

\section{Standard Criticisms of Schuck and Smith}

There are many points that could be made in response to the revisionist interpretation, but the two that are the most germane to this historical analysis relate to the textual meaning of jurisdiction and to the presence (or lack thereof) of illegal aliens when the Fourteenth Amendment was written. ${ }^{65}$ The first objection puts a lot of pressure on Schuck and Smith's invocation of the Tribes' status as support for their approach, while the latter calls their entire project into question.

All of the confident assertions that the word "jurisdiction" in the Citizenship Clause means "allegiance or consent" run up against the problem that this is not how the term is usually defined. ${ }^{66}$ Justice Holmes gave the standard explanation that "[j]urisdiction is power," by which he meant that the willingness of a party to be hailed before a court is irrelevant. ${ }^{67}$ For example, it would be strange if a criminal defendant could assert a defense based on his lack of consent to the State's prosecutorial authority. Likewise, illegal aliens in deportation proceedings would not get far by asserting that the tribunal lacked

64 Given the lax enforcement of the immigration laws, one could say that the United States is granting tacit consent to the presence of illegal aliens. The best understanding of the Schuck and Smith position, however, is that formal consent is required by both parties for birthright citizenship.

65 One of these criticisms would be on stare decisis grounds, which Schuck and Smith dismiss as a "reflexive acceptance and legitimation of the status quo." SCHUCK \& SMITH, supra note 5, at 131. Another would address the pragmatic implications of any interpretive change, such as the loss of "administrative clarity and simplicity of the current birthright citizenship rule." Id. at 133 .

66 See NEUMAN, supra note 8, at 171 ("The word jurisdiction has various meanings in American law, but it has never been defined in terms remotely resembling the elaborate construct on which the revisionist argument depends.").

67 Cordova v. Grant, 248 U.S. 413, 419 (1919); see James C. Ho, Defining "American": Birthright Citizenship and the Original Understanding of the Fourteenth Amendment, 9 GREEN BAG 2D 367,368 (2006) ("When we speak of an individual who is subject to the jurisdiction of a court, he must follow the judgments and orders of that court, whether he likes it or not."). 
jurisdiction because they did not consent. ${ }^{68}$ This does not mean that an alternative reading is incorrect. ${ }^{69}$ It does indicate, however, that Schuck and Smith must rely on legislative history, rather than on the ordinary meaning of the text, to make their case. And as stated earlier, their principal source is the debate on the Tribes. ${ }^{70}$

The other obstacle to the revisionist argument is that illegal aliens were here when the Fourteenth Amendment was ratified, and tbey received birth citizenship just like everyone else under the authority of the United States. A common refrain among critics of the current constitutional custom is that there were no illegal immigrants when the Citizenship Clause was written; hence, the drafters did not consider the problem. ${ }^{71}$ While it is true that no general immigration statute was enacted until after Reconstruction, Gerald L. Neuman points out that the immigration (or importation) of slaves was barred long before the Civil War. ${ }^{72}$ Nonetheless, illegal smuggling of slaves was widespread and tens of thousands entered the country in this fashion. ${ }^{73}$ Presumably, under a mutual consent theory of birthright citizenship, the children of these illegal slaves could not be citizens. ${ }^{74}$

68 Indeed, one could say that illegal aliens are illegal precisely because they are subject to the jurisdiction of the authorities under federal immigration law.

69 On the other hand, the Supreme Court held that illegal immigrants are "within the jurisdiction" of the states pursuant to the Equal Protection Clause. Plyler v. Doe, 457 U.S. 202, 211-13 (I982). Thus, a persuasive explanation is required to show why "subject to the jurisdiction" should be read differently. See SCHUCK \& SMITH, supra note 5, at 157-58 n.40 (arguing that the words "subject to" and "within" bear different constructions); Wood, supra note 6 , at 520 (arguing that equal protection is not a zero-sum game the way citizenship is).

70 See supra text accompanying notes $56-62$.

71 See SCHUCK \& SMITH, supra note 5, at 95; Wood, supra note 6, at 515.

72 See Plyler, 457 U.S. at 205 ("Since the late 19th century, the United States has restricted immigration into this country."); NEUMAN, supra note 8 , at 178 (describing the ban on the foreign slave trade); see also U.S. CONST. art. I, $\$ 9$, cl. 1 (prohibiting Congress from restricting the "Migration or Importation" of slaves until 1808); Act of Mar. 2, 1807, ch. 22, 2 Stat. 426 (prohibiting the importation of slaves into the United States as of January I, 1808). Neuman also says that illegal immigrants were familiar to the Framers of the Fourteenth Amendment because states regulated immigration during the antebellum years. See NEUMAN, supra note 8, at 176-78.

73 See NEUMAN, supra note 8, at 179 ("Conservative estimates of the numbers of illegally imported slaves put them in the tens of thousands."); C. VANN WOODWARD, AMERICAN COUNTERPOINT 82 (1971) (stating that an estimate of 54,000 for the number of illegal slaves imported into the United States from 1808 to 1861 is "persuasive"). These captives were subject to deportation back to Africa. See Act of Mar. 3, 18I9, ch. 101, 3 Stat. 532, 533 (authorizing the President to regulate the deportation of "all such negroes, mulattoes, or persons of colour" who are brought to the United States in connection with the slave trade).

74 See NEUMAN, supra note 8, at 179 ("There is no consistent principle by which the citizenship clause can be interpreted as simultaneously including all native-born former slaves 
Since an interpretation of the Fourteenth Amendment that does not make all African Americans citizens is patently absurd, the reciprocal allegiance theory appears inadequate. ${ }^{75}$

Neuman's challenge postdates Schuck and Smith's book, but there are at least two responses to his point on slavery. The first is that the transformative thrust of the Fourteenth Amendment on the issue of racial justice could be read broadly to grant birth citizenship to African Americans in spite of their illegal status. ${ }^{76}$ If that sounds too radical, a more conventional answer is that the illegally imported slaves were relatively few in number and constituted a de minimus exception to the mutual consent principle that cannot be applied to the much greater number of illegal immigrants arriving now. ${ }^{77}$ For those who hold that there should be no exceptions based on sheer numbers, it is worth noting that the common law's exclusion for enemy aliens in hostile occupation could easily be described as a de maximus exception to a territorial rule of birthright citizenship. This suggests that the enemy alien category deserves more scrutiny than it gets in the current debate on how illegal aliens should be treated, both on the slavery point and as a more general source of guidance.

In sum, the revisionist argument against birthright citizenship for children of illegal immigrants turns on how the Framers of the Fourteenth Amendment conceptualized the Tribes' status under the Citizenship Clause. Although Schuck and Smith do an admirable job of parsing the legislative history, the next Part explores the abolitionist background that they ignore.

and excluding all children of parents to whose entry into the country the nation has not consented.").

There is no indication in the legislative history, however, that the Framers of the Fourteenth Amendment ever considered the issue of illegal slaves.

An analogous problem arose when the first African-American senator presented his credentials to the Senate Chamber in 1870 , and Democrats asserted that he was ineligible to serve as a senator because the Constitution requires senators to have been citizens for nine years. See Richard A. Primus, The Riddle of Hiram Revels, 119 Harv. L. Rev. 1681, 1682-85 (2006) (exploring the constitutional and substantive justice aspects of the Senate debate). Since the Fourteenth Amendment was ratified in 1868, no African American in 1870 could claim nine years of citizenship without: (1) a rather creative reading of the requirement, or (2) an acknowledgement that Reconstruction worked a significant change on behalf of racial equality that altered the textual meaning.

Another, less plausible answer to the illegal alien point holds that "it is at least misleading to claim that there were illegal aliens at the time of the framing of the Fourteenth Amendment" because these aliens did not face "a significant risk of deportation." Wood, supra note 6, at 490 . Even if this were true, it is not clear why the means used to enforce immigration laws is relevant to the question of their status with respect to birthright citizenship. 


\section{BIRTHRIGHT CITIZENSHIP AND THE TRIBES}

This Part explores the reasons behind the decision to declare the Tribes beyond the nation's jurisdiction, and links that choice to the broader relationship between the Fourteenth Amendment and Native Americans. Though the abolitionist movement was primarily concerned with securing basic rights and equal treatment for African Americans, discrimination against Native Americans also influenced their thinking about these issues. Schuck and Smith, like almost all other interpreters of Reconstruction, miss this point and fail to see that the "subject to the jurisdiction" clause was actually part of an effort to enhance tribal rights rather than restrict them. Thus, this language does not have an exclusionary cast that can be extended by construction to give Congress the discretion to deny birthright citizenship for illegal alien children.

\section{A. The Trail of Tears and the March of Freedom}

The catalyst for the popular mobilization that gave us the Fourteenth Amendment was the removal of the Cherokees from Georgia. ${ }^{78}$ Prior to that time, most anti-slavery activists supported the deportation of slaves, not abolition, as the best solution. ${ }^{79}$ When President Andrew Jackson sought to impose a similar policy on the Cherokee Tribe by shipping them into exile west of the Mississippi, however, these leaders were appalled by its brutal reality. ${ }^{80}$ Indeed,

78 The argument presented in this portion of the text is developed at much greater length in my recent book on Jacksonian Democracy and the Constitution. See Macliocca, supra note 14 , at 88-93, 118-23.

79 See Mary Hershberger, Mobilizing Women, Anticipating Abolition: The Struggle Against Indian Removal in the 1830s, $86 \mathrm{~J}$. AM. HIST. 15, 35 (1999) (noting that even William Lloyd Garrison, the vocal abolitionist and editor of the Liberator, supported colonization as late as 1829); see also RONALD G. WALTERS, THE ANTISLAVERY APPEAL: AMERICAN ABOLITIONISM AFTER 1830, at xi (1976) (noting that the sudden conversion of the leaders of the antislavery movement to an abolitionist view during the 1830 s "haunts everything written on the subject").

80 See Andrew Jackson, First Annual Message (Dec. 8, 1829), in 2 A COMPILATION OF THE MESSAGES AND PAPERS OF THE PRESIDENTS, 1789-1897, at 442, 458 (James D. Richardson ed., 1897) (stating that he informed "the Indians inhabiting parts of Georgia and Alabama that their attempt to establish an independent government would not be countenanced by the Executive of the United States, and advised them to emigrate beyond the Mississippi or submit to the laws of those States"); Linda K. Kerber, The Abolitionist Perception of the Indian, 62 J. AM. HIST. 271, 272-73 (1975) (describing the activities of the antislavery activists against the Removal Act and noting their shift shortly thereafter to an abolitionist position); LIBERATOR, July 21, 1832, at 114 (attacking "Andrew Jackson, and all his subordinate land-stealing, negro-thieving, missionary-persecuting, and Cherokeemurdering gang"); see also RONALD N. SATZ, AMERICAN INDIAN POLICY IN THE JACKSONIAN 
many of them said that this experience transformed their views on slavery. For example, James Birney abandoned colonization in the 1830 s because of the "very great resemblance it bears, in its most prominent features, to that of the lndians, who have been moved upon, in nearly the same manner to 'consent' to leave their lands." Likewise, William Lloyd Garrison said slaves were "as unanimously opposed to a removal to Africa, as the Cherokees from the councilfires and graves of their fathers" and connected these issues in his new abolitionist paper, the Liberator. ${ }^{82}$

As the abolitionists gathered strength over the next three decades, they often invoked the Cherokee Removal as part of a broader argument that Native American and African American freedom were inextricably linked. ${ }^{83}$ lndeed, "[f] ew comments are more common in their speeches than that their goal was that both blacks and Indians be secured in their rights as men." ${ }^{, 84}$ They were particularly fond of

ERA 101 (1975) ("One Georgia volunteer engaged in removing the Cherokees remarked years later, ' 1 fought through the civil war and have seen men shot to pieces and slaughtered by thousands, but the Cherokee removal was the cruelest work I ever knew."').

Letter from James Gillespie Birney, Late Vice President, Ky. Colonization Soc'y, to Reverend Thorton J. Mills, Corresponding Sec'y, Ky. Colonization Soc'y (July 15, 1834), in NEw YORK OFFICE OF THE ANTI-SLAVERY REPORTER (1834); see BERIAH GREEN, SKETCHES OF THE LIFE AND WRITINGS OF JAMES GILleSPIE BIRNEY I0 (Utica, NY, Jackson \& Chaplin 1844) (" $[\mathrm{F}]$ rom the Indian to the Negro, the transition was easy and natural ... . [Birney] could hardly fail to see, when the wrong of the Indians had thoroughly aroused him, that the sufferings of the Negro flowed from the same bitter fountain."); Letter from James Birney to Joshua Leavitt and Others(Jan. I0, 1842), in 2 LETTERS OF JAMES GILleSPIE BIRNEY 1831-1857, at 645, 652 (Dwight L. Dumond ed., 1938) (statement upon being offered the presidential nomination of the Liberty Party) ("We have so long practiced injustice, adding to it by hypocrisy, in the treatment of the colored race, both negroes and Indians, that we begin to regard injustice as an element-a chief element-the chief element in our government.").

82 Henry Mayer, All on Fire: William lloyd Garrison and the Abolition of SLAVERy 138 (1998) (internal quotation marks omitted); see LibERATOR, Jan. 26. 1833, at 15 ("So said the government of Georgia, in regard to the removal of the Indians-we don't compel them to go. No, Sir, they did not compel the Indians to go; but then, they rendered them so uncomfortable, by their oppression and injustice, that the poor Indians can't stay. And just so it is, Sir, with the Blacks."); see also MAGLIOCCA, supra note I4, at 91 (reproducing the masthead of the Liberator that depicted a slave auction being conducted on top of trampled "Indian treaties").

83 See, e.g., 8 Charles Francis Adams, Diary of Charles Francis Adams 50 (Aida Donald \& David Donald eds., I964) ("It is Slavery that is at the bottom of this. I am more satisfied of the fact every day I live."); see also Kerber, supra note 80, at 277-78 (explaining that the Massachusetts Anti-Slavery Society's Annual Report in 1838 focused on the Cherokee Removal).

84 Kerber, supra note 80, at 290; see ROBERT WINSTON MARDOCK, THE REFORMERS AND THE AMERICAN INDIAN 12 (I971) (quoting the abolitionist view that slavery was "an extension of the unneighborly, unChristian, and destructive practice which for generations has been operating against the Aborigines" (internal quotation marks omitted)); John 
Chief Justice Marshall's opinion in Worcester $v$. Georgia, ${ }^{85}$ where he tried (unsuccessfully) to protect the Cherokees and the missionaries in their midst by articulating a broad view of tribal sovereignty. ${ }^{86}$ Consequently, anti-slavery leaders invoked Worcester as a milestone in the struggle for universal freedom. ${ }^{87}$

The bond between African-American and Native-American liberty remained vital when the abolitionist generation reached the summit of power during Reconstruction. ${ }^{88}$ As the National Anti-Slavery Standard stated, one of the "good results of the abolition of chattel slavery, and of the ... iniquitous system, [is] that a more just policy is now sought and recommended in relation to the Indians., ${ }^{, 89}$ While the famed Joint Committee on Reconstruction was proposing the Fourteenth Amendment and investigating the conditions of the freedman, a similar Joint Committee on the Tribes was looking into their situation and advancing a series of broad reforms. ${ }^{90}$ And in a direct rebuke to Jackson's treatment of the Cherokees, the Senate Judiciary Committee declared that Worcester was "the unquestioned law of the

Greenleaf Whittier, Letter from the Editor, PA. FreEmaN, May 10, 1838, at 2 ("The same despotic, cruel, and diabolical spirit that oppresses the African race, acts in all its unearthly force and virulence against the poor Indians.").

8531 U.S. (6 Pet.) 515 (1832).

86 See MAGLIOCCA, supra note 14, at 42-51, 92-93 (exploring the political context surrounding the case and the reasons why abolitionists seized upon it); Diary Entry of Salmon P. Chase (July 2, I843), in 1 THE SAlmon P. ChaSe PAPERS, Journals, I829-1872, at 169, 169 (John Niven et al. eds., 1993) (quoting a pastor who "asked for the deliverance of the land from Slavery among other sins \& evils \& in Sermon spoke of the imprisonment of Butler \& Worcester in Geo[rgia] Penitentiary").

87 See, e.g., Cong. Globe, 34th Cong., 3d Sess. app. at 135, 139 (1857) (statement of Rep. Bingham) ("The extra-territorial legislative power of every State is limited to its own citizens and subjects. That is the decision of the Supreme Court, in the great case of Worcester $v s$. the State of Georgia ... The Constitution is based upon the EQUALITY of the human race."); Ableman v. Booth, 11 Wis. 498, 529 (1859) (quoting an abolitionist pamphlet stating that "Georgia's resistance to the appellate jurisdiction of the [S] upreme [C]ourt first sprung from jealousy of interference with the "peculiar institution"”).

88 See, e.g., CONG. GLOBE, 40TH CONG., 2D SESS. 1956 (I868) (statement of Rep. Broomall) (refuting the doctrine "that black men and red men have no rights whatever except by the grace and favor of the white men"); CONG. GLOBE, 38th Cong., 2d Sess. 260 (1865) (statement of Rep. Rollins) (rejecting the doctrine that the Declaration of Independence "was applicable alone to white men, and not to the black man, the red man, or any other than the white man").

89 NAT'L ANTI-SLAVERY STANDARD, Apr. I0, 1869; see MARDOCK, supra note 84, at 48 (quoting Wendell Phillips's view that the "great poison of the age is race hatred .... We must see the man, not the negro, the man and not the Indian, the man and not the Chinaman").

90 See S. REP. NO. 39-I56, at 1-4 (1867) (summarizing the findings of the Joint Committee on the Tribes). 
court to-day" that "no man acknowledging the authority of reason can gainsay."

The critical point is that Reconstruction Republicans also used Worcester and the Cherokee Removal as interpretive guides for the Fourteenth Amendment. For instance, the drafter of Section 1, John Bingham, told his constituents and colleagues that " $[u]$ nder the Constitution as it is, not as it was, and by force of the $[F]$ ourteenth [A] mendment, no State hereafter can ... ever repeat the example of Georgia and send men to the penitentiary, as did that State, for teaching the lndian to read the lessons of the New Testament." ${ }^{\text {"2 }}$ Other Members of Congress echoed this cite to Worcester since they could "certainly recollect twenty-five or thirty years ago when the whole country rang with moral indignation against the treatment of those Indians by citizens of Georgia." ${ }^{99}$ As one congressman from Massachusetts said, "The principal danger that menaces us to-day is from the effort within the States to deprive considerable numbers of persons of the civil and equal rights which the General Government is endeavoring to secure to them., ${ }^{, 4}$ Given that context, " $[t]$ he history of the Indian tribes within our jurisdiction is an instructive lesson .... In the famous case of the Georgia Indians, the judiciary of the nation went to the extreme of its power in protecting the rights of the weak and defenseless. ${ }^{, 95}$

S. REP. No. 41-268, at 6-7 (1870) (examining the relationship between the Tribes and the Fourteenth Amendment).

CONG. Globe, 42d Cong., lst Sess. app. at 84 (1871) (statement of Rep. Bingham); see Adamson v. California, 332 U.S. 46, 74 (1947) (Black, J., dissenting) (describing Bingham as the "Madison of the first section of the Fourteenth Amendment"); CINCINNATI DAILY COMMERCIAL, Aug. 10, 1866, at 1 ("If you rally at the fall ... depend upon it that every State South will rally to the lead of Tennessee, and ratify the Amendment. Is not that worth striving for? Then hereafter, in Georgia, men shall not be imprisoned, as in the past, for teaching the lowly to read in the New Testament of another and a better life." (quoting Bingham's statement in a campaign speech)). Indeed, this was the one example that Bingham always used to explain why we needed the Fourteenth Amendment.

CONG. Globe, 41 st Cong., 2d Sess. 1671 (1870) (statement of Rep. Maynard); see ConG. GLOBE, 40th Cong., 3d Sess. app. at 142 (1869) (statement of Rep. Burleigh) ("Every student of American history must remember the excitement which this [Removal] treaty produced throughout the country and the influence it exerted upon our national politics."); CONG. GloBE, 39th Cong., 1st Sess. 1684 (1866) (statement of Rep. Stevens) ("I remember, sir, when a law was passed by the State of Georgia extending the jurisdiction of that State over the Indian lands within the State ... . I trust that we shall never disgrace the national legislation by any act which will give the sanction of law to such an outrage as I have cited."). 
There are powerful implications from this deliberate decision to incorporate Native Americans into Fourteenth Amendment analysis. First, this experience adds a new facet to many of the guarantees in the Bill of Rights that were applied to the States by Section $1 .^{96}$ A prior article of mine explained how Bingham's reliance on Worcester to define religious freedom undermines the Supreme Court's holding in Employment Division v. Smith. ${ }^{97}$ Likewise, judges and scholars could obtain new insights into the Second Amendment by examining how gun regulations applied to Native Americans. ${ }^{98}$ Second, the concept of equality is changed in subtle ways once the interpretive baseline is expanded beyond African Americans. ${ }^{99}$ Native Americans could be defined in racial terms, but they could also be defined by their cultural practices involving religion, marriage, and lifestyle. ${ }^{100}$ If these choices are integrated into an equal protection analysis, then this opens up new ways to assess the State's power to enforce moral standards. ${ }^{10}$

\section{B. Worcester and the Citizenship Clause}

Most of the time, the history laid out in the previous Section is ignored when the Fourteenth Amendment is applied, largely because the African American paradigm totally eclipsed its tribal counterpart in the twentieth century. The Citizenship Clause is the exception to

96 This view holds whether one thinks that the Framers of the Fourteenth Amendment intended to incorporate the Bill of Rights, see CONG. GLOBE, 42d Cong., 1st Sess. app. at 84 (1871) (statement of Rep. Bingham), or rests on the conclusion that the Due Process Clause of Section 1 selectively incorporates those rights, see Palko v. Connecticut, 302 U.S. 319, 325-36 (1937).

97494 U.S. 872, 878-79 (1990) (holding that the Free Exercise Clause is not violated when a neutral law imposes a substantial burden on religious practice); see Magliocca, supra note 62 , at $953-60$ (criticizing this decision).

98 When one Senator asked whether the Fourteenth Amendment would invalidate state laws that barred whites from selling guns and alcohol to Native Americans, see CONG. GLOBE, 39th Cong., 1st Sess. 573 (1866) (statement of Sen. Williams), the reply only defended the state's power to regulate alcohol sales, see id. (statement of Sen. Henderson). The Takings Clause is another provision that bears reexamination, as the confiscation of tribal land without compensation is a powerful legacy of our country's history.

99 See Magliocca, supra note 62, at 960-65. One discrimination case that cried out for a comparison to the Cherokee Removal was the wartime internment of Japanese-Americans. See Korematsu v. United States, 323 U.S. 214, 219 (1944).

100 See United States v. Joseph, 94 U.S. 614, 617 (1877) (holding that the Pueblos did not qualify as a Tribe because they did not share the cultural practices of other Native Americans); $i d$. at 616 (describing the Pueblo as "Indians only in feature [and] complexion").

101 For a thoughtful discussion of the tension between individual autonomy and cultural assimilation, see generally KENJI YOSHINO, COVERING: THE HIDDEN ASSAULT ON OUR CIVIL RiGHTS (2006). 
this trend, and thus Schuck and Smith deserve credit for seeing the importance of the Tribes in this context. And because information on the link between Worcester and the Fourteenth Amendment was not available when they wrote their book twenty years ago, their failure to consider the issue is understandable. Nevertheless, that evidence refutes Schuck and Smith's analysis, demonstrating that the exclusion of the Tribes from citizenship was done out of respect for Worcester and not to import a reciprocal consent principle. ${ }^{102}$

The Framers of the Fourteenth Amendment worried that a grant of birthright citizenship would undermine the autonomy that Worcester held was a fundamental right of the Tribes. As the Senate Judiciary Committee said, "an act of Congress which should assume to treat the members of a tribe as subject to the municipal jurisdiction of the United States would be unconstitutional and void" unless it is "consistent with their character as separate political communities or states." ${ }^{\text {Fo3 }}$ Furthermore, Senator Trumbull said that it would be "a breach of good faith on our part to extend the laws of the United States over the Indian tribes... in which treaties we have agreed that we would not make them subject to the Iaws of the United States." 104 Critics of this reading (and there were many) replied that all Native Americans were entitled to citizenship, because otherwise they would not be treated equally. ${ }^{105}$ In this respect, there was a tension between Worcester's vision of tribal sovereignty and the ideal of equal citizenship, which was resolved by holding that members of Tribes were not

102 This was not, of course, the only motivation for excluding the Tribes. For instance, Senator Trumbull explained that Indians at war with the United States could not be given citizenship. See CONG. GLOBE, 39th Cong., Ist Sess. 527 (1866) (statement of Sen. Trumbull) ("Of course we cannot declare the wild Indians who do not recognize the Government of the United States at all ... to be the subjects of the United States in the sense of being citizens. They must be excepted.").

103 S. REP. NO. 4I-268, at 9-I0 (1870). See generally id. at 9-1 I (analyzing the relationship between the Fourteenth Amendment and the Tribes).

104 CONG. GLOBE, 39th Cong., 1st Sess. 2894 (1866) (statement of Sen. Trumbull); see also S. REP. NO. 4I-268, at 11 (stating that the United States could not abrogate these treaties unilaterally through passage of the Fourteenth Amendment). If this were the only objection to tribal citizenship, then Schuck and Smith's mutual consent theory would stand on solid ground. The problem is that consistency with Worcester was the primary concern.

105 Compare CONG. GlOBE, 39th Cong., 1st Sess. 574 (1866) (statement of Sen. Henderson) ("We are deciding to-day that [the Constitution] was made for the white man and the black man, but that the red man shall have no interest in it."), with id. (statement of Sen. Trumbull) ("We are not deciding any such thing."). For a sample of the views in favor of full Native American citizenship, see CONG. GLOBE, 41st Cong., 2d Sess. 1670 (I870) (statement of Rep. Paine), CONG. GlOBE, 41st Cong., 2d Sess. I25-26 (1869) (statement of Rep. Niblack), and CONG. Globe, 4 Ist Cong., 1st Sess. 559-60 (I869) (statement of Rep. Butler). 
citizens but that individual Native Americans who were not members of Tribes would be considered citizens. ${ }^{106}$

The debate and contemporaneous reading of the Citizenship Clause, as informed by the abolitionist movement, does not support the claim that the "subject to the jurisdiction" requirement changed the traditional understanding of birthright citizenship. It is clear that the Framers of the Fourteenth Amendment did not write the jurisdiction provision to transform the law in this area. Instead, they wanted to rescue the common law rule from the clutches of Dred Scott and restore the authority of Worcester, which for all practical purposes was a nullity during the Jacksonian era. ${ }^{107}$ This conclusion is confirmed by the fact that there is nothing specific in the legislative history about limiting birthright citizenship through a mutual allegiance theory, whereas there are specific references to the common law and Worces$t^{2}{ }^{108}$ Since Schuck and Smith must rely on original understanding to overcome the ordinary textual meaning given to jurisdiction, this lack of support in the historical record is fatal to their claims.

Another way to look at the significance of Worcester for the revisionist claim relates to the rule of construction that should apply to the Citizenship Clause. Schuck and Smith could be saying that the "subject to the jurisdiction" language is ambiguous with respect to illegal aliens and should receive an exclusionary reading. From the sources considered here, however, there can be little doubt that the drafters excluded the Tribes because they felt that this was the best way to maximize Native Americans' rights. ${ }^{109}$ Turning around and construing that text to eliminate unambiguously the rights of a class of children is not consistent with the underlying purpose of the provision with respect to the Tribes. ${ }^{110}$ The Framers of the Fourteenth

106 See Elk v. Wilkins, 112 U.S. 94, 112 (1884) (Harlan, J., dissenting) (stating that the Civil Rights Act of 1866 was "the first general enactment making persons of the Indian race citizens of the United States"); id. at 120 (citing Cooley's treatise for the proposition that a Native American not affiliated with a tribe had the same rights "as that of any other native born inhabitant").

107 See MAGLIOCCA, supra note 14, at 69-73, 94-96 (descrihing Worcester's moribund status during the preceding thirty years).

108 Accordingly, the stray comments about "allegiance" and "consent" that are cited by Schuck and Smith simply cannot bear the weight that they put on them. See supra notes 57-62 and accompanying text.

109 It goes without saying that this strategy did not work well. See Magliocca, supra note 62, at 949-52 (exploring what happened following Reconstruction).

110 See Martin, supra note 5, at 295 (stating that reciprocal consent is a harmful principle "when society excludes those who realistically have no home elsewhere and therefore deserve the status of member in the only national society to which they are connected. This was the essential vice of Elk $v$. Wilkins and Dred Scott"). 
Amendment viewed exclusion as a necessary evil that was imposed over the objections of those who wanted full Native American citizenship. Extending this decision by construction is therefore not appropriate, particularly given all of the other interpretive objections to such a move.

In sum, the bond between abolitionists and Native Americans works against the revisionist interpretation of the Citizenship Clause by showing that the exclusion of the Tribes was based on respect for the principles enunciated in Worcester. The discussion now turns to the question of whether some other theory can justify the repeal of birth citizenship for illegal immigrants.

\section{INVASION AND EVASION}

This Part contends that any sound analysis of illegal alien citizenship must rest on a comparison to the common law exception for enemy aliens in hostile occupation of a sovereign's land. Schuck and Smith's tribal analogy only confuses matters because there is no conceptual similarity between the original native-born inhabitants of our country and its most recent immigrants. Yet there is a potential parallel between foreign invaders and illegal aliens, who both enter the country unlawfully and are subject to expulsion. Accordingly, the operative question is whether illegal aliens, like enemy occupiers, are beyond the actual authority of the United States. The answer to this constitutional question is no.

\section{A. The Relevance of Foreign Soldiers}

No exception to the rule of birthright citizenship comes closer to the dilemma raised by illegal immigrants than the one reserved for enemies in hostile occupation."' In each case, the host country has legal jurisdiction over the intruders and does not want them on its soil. ${ }^{112}$ The problem is that the government cannot enforce its will,

111 The United States has never invoked this exception to birthright citizenship, though the issue has arisen in other contexts when U.S. territory was occupied. See United States v. Rice, 17 U.S. (4 Wheat.) 246 (1819) (holding that the British occupation of towns in Maine (then part of Massachusetts) during the War of 1812 suspended the operation of customs laws there).

112 There could be some narrow exceptions under international law, whereby a sovereign would not have a lawful right to eject foreign invaders, but that need not concern us here. The fact that lawful combatants are exempt from ordinary judicial process under the Geneva Conventions is irrelevant because the home country has the right to detain those 
which is relevant because the common law held that a sovereign must be in actual possession of power to confer birthright citizenship. ${ }^{113}$ With respect to a hostile army hunkered down in Massachusetts, this lack of authority is comprehensive until the force is destroyed or driven out. When it comes to illegal aliens, the problem lies with the administrative task of finding the wrongdoers when they can hide in plain sight. ${ }^{114}$

Putting aside the legal similarities between illegal immigrants and enemy aliens in hostile occupation, the comparison also makes sense given that many Americans see both as threats. Illegal aliens are not enemies in the sense of the common law because they almost all come from friendly or neutral nations in Latin America. One might conclude, though, that these illegal workers are an economic threat because they drive down wages for some citizens or lawfully admitted aliens. Similarly, one could say that these migrants pose some kind of cultural danger because they do not speak English or do not adhere to our values. Of course, these claims can be and often are challenged. The point is that opponents of illegal immigration are far more likely to make a connection with enemy invaders than with Native American Tribes, whose relationship to the issue is not at all obvious.

\section{B. An Issue of Enforcement}

If the proper analogy is with enemy aliens in hostile occupation, then the next issue worth considering is the degree of authority required to meet the jurisdictional element of the Citizenship Clause. Foreign armies are beyond the sovereign's control in a way that is not comparable to illegal aliens. Nevertheless, that does not mean that

troops and hold them as prisoners of war. See Geneva Convention Relative to the Treatment of Prisoners of War, Aug. 12, 1949, 6 U.S.T. 3316, 75 U.N.T.S. 135.

113 See Inglis v. Trs. of Sailor's Snug Harbour, 28 U.S. (3 Pet.) 99, 155 (1830) (Story, J., dissenting) (" $[\mathrm{T}]$ he party must be born within a place where the sovereign is at the time in full possession and exercise of his power ...."). Though the principal issue for asserting jurisdiction over the Tribes was a formal recognition of their sovereignty, it must be conceded that some of them were strong enough to block the United States from asserting its authority in a concrete way.

114 One could say that the comparison is inappropriate because the common law exceptions involved the official representatives of the sovereign (soldiers or ambassadors). Cf. Schooner Exch. v. McFaddon, 11 U.S. (7 Cranch) 116, 144 (1812) (holding that foreign visitors are not exempt from the home country's jurisdiction unless they are employed by the sovereign or "engaged in national pursuits"). Nevertheless, there is nothing about official status that bears on the issue of whether the United States has actual, as opposed to formal, jurisdiction over the individuals in question. 
the United States' authority over the latter group is sufficient to say that they still qualify for birthright citizenship.

The best argument for the proposition that the enemy alien exception encompasses illegal aliens comes from Charles Wood, the former counsel to the Senate Judiciary Committee's Subcommittee on Immigration. ${ }^{15}$ Wood says that "it would be reasonable for Congress to conclude that illegal aliens are not 'subject to' the jurisdiction of the government... and that the federal government's actual power to bring illegal aliens to justice is insufficient to satisfy the constitutional standard for birthright citizenship." 16 Indeed, "[i]t seems indisputable that such power is substantially less than the power with respect to other violators of the law."117 That is true because "it is essentially only their status, and not their actions, which distinguishes them from the law-abiding persons around them" and so "they face relatively little risk of being brought to justice." 118

Conceding that there are difficulties involved in apprehending illegal aliens, the problem with Wood's argument is that the United States could be doing a lot more to enforce its borders. Opponents of illegal immigration never tire of pointing out that we could build fences along the Rio Grande, crack down on corporations that hire illegal aliens (by reviewing their Social Security information), or refuse to give these immigrants a driver's license. ${ }^{119}$ These are just a few of the measures that could be taken if the political community really wanted to address the issue. The failure to enforce the immigration laws is not about a practical inability to do so; rather, it is about the practical conclusion that robust enforcement is not worthwhile. Whether that choice is right or wrong, a blasé attitude is a far cry from the impossibility of enforcing the sovereign's will.

Wood anticipates the force of this objection, and his answer is that "even if the probability of their apprehension and prosecution were greatly increased it is unlikely ever to be equivalent to that of other lawbreakers." ${ }^{20}$ Even if this claim is correct, the question is why con-

115 See Wood, supra note 6, at 510-11 (arguing that the government's inability to actually bring illegal aliens to justice exempts them from birthright citizenship); $i d$. at $465-66$ (giving Wood's credentials and outlining his argument generally).

116 Id. at 510.

$117 I d$.

118 Id.

119 For a thoughtful discussion on the driver's license question, see María Pabón López, More Than a License to Drive: State Restrictions on the Use of Driver's Licenses by Noncitizens, 29 S. ILL. U. L.J. 91 (2004).

120 Wood, supra note 6, at 511. 
stitutional jurisdiction requires an enforcement level that is equal to other wrongdoers. Just as it is inadmissible for a criminal defendant to assert that jurisdiction is lacking because she did not consent to the tribunal, a claim that there is no jurisdiction because the enforcement of this crime was not equivalent to that of other crimes would be laughed out of court. ${ }^{121}$ As with Schuck and Smith's mutual consent approach, the ordinary meaning of jurisdiction does not support Wood's interpretation on this score.

Not surprisingly, Wood defends his unorthodox reading of jurisdiction by citing the same legislative history about the Tribes that Schuck and Smith used to support their theory. For instance, he implies that Senator Howard's declaration that "full and complete" jurisdiction is required by the Citizenship Clause that is "the same jurisdiction in extent and quality as applies to every citizen of the United States now" supports a rule of enforcement parity. ${ }^{122}$ No such conclusion is warranted. First, these comments were made about the lack of formal, not actual, authority with respect to the Tribes, and thus say nothing relevant about the issue Wood wants to talk about. Second, for the reasons stated in Part II, construing the Fourteenth Amendment's treatment of the Tribes in an exclusionary manner is inconsistent with its Framers' intent. Third, complete sovereignty does not mean that there will always be effective law enforcement. The fact that it is harder to catch certain types of criminals simply does not affect jurisdiction unless the enforcement gap is acute and impossible to cure. ${ }^{123}$

In sum, the only analytic framework that makes sense for the issue of birthright citizenship for illegal alien children is a comparison to the exception for enemy aliens in hostile occupation. Although the jurisdiction element of the Citizenship Clause does require the United States to exercise real authority over its territory, there is no reason to think that the government could not do so with respect to illegal immigrants if it actually tried. Perhaps this issue could be re-

121 See supra notes 66-70 and accompanying text (explaining how the ordinary use of jurisdiction contradicts the mutual allegiance interpretation).

122 Wood, see supra note 6, at 508-10 (quoting CONG. GLOBE, 39th Cong., 1st Sess. 2895 (1866) (statement of Sen. Howard) (emphasis in Wood)); supra notes 58-59 and accompanying text (showing how Schuck and Smith rely on these quotes). 1 use the word "implies" because Wood never really develops this point, but it is the most logical reading of the relevant passage in his article.

123 Furthermore, it is far from clear that immigration violations are inherently more difficult to enforce than arguably victimless crimes like prostitution or gambling. As a result, the premise that even a full-court press would not yield constitutionally adequate enforcement to qualify as jurisdiction is probably wrong. 
visited if the federal government took strong action that came to naught; but under present circumstances, the only reasonable conclusion is that jurisdiction does exist and birth citizenship does apply. ${ }^{124}$

\section{CONCLUSION}

There is undoubtedly some tension between the right of a nation to control its borders and a rule of birthright citizenship that applies to illegal aliens. From the common law, we have inherited a welcoming tradition that considers birthright citizenship too precious to be left in the hands of Congress. Though the federal government retains broad discretion to deport illegal immigrants, any child born under the legal and actual authority of the United States is a citizen. The revisionist arguments by Schuck and Smith cannot overcome the formidable authority standing in their way.

Nevertheless, Schuck and Smith's analysis provides a valuable service by focusing attention on the relationship between the Native American Tribes and the Fourteenth Amendment. Sadly, the neglect that breeds hopelessness on reservations even today is matched by the indifference of lawyers toward the role that tribal life played in the evolution of our great guarantees of freedom. By probing the citizenship claims of outsiders, Schuck and Smith end up exposing a new paradigm for thinking about the rights of all Americans.

124 Put another way, Congress should not be able to alter longstanding constitutional doctrine on birthright citizenship by just asserting that they lack the necessary authority over illegal immigrants. Instead, Congress should be put to the test and demonstrate that it cannot deport or drive out this population, even by using the full might of the federal government. 